\title{
IN VITRO CHEMICAL MUTAGENESIS FOR ENHANCING VARIABILITY IN BANANA CULTIVAR NANJANAGUDU RASABALE
}

\author{
KISHOR. $\mathbf{H}^{1}$, ABHIJITH. Y. $\mathrm{C}^{2}$ \& MANJUNATHA. $\mathrm{N}^{3}$ \\ ${ }^{1}$ Aeroponics Centre, PRS Horticulture Farm, Department of Horticulture, Chikkaballapura, Karnataka, India \\ ${ }^{2}$ Department of Fruit Science, College of Horticulture, GKVK, Bengaluru, India \\ ${ }^{3}$ Department of Fruit Science, College of Horticulture, Kolar, Karnataka, India
}

\begin{abstract}
Nanjanagudu Rasabale, also known as Rasthali in Tamil Nadu, is one of the favorite banana cultivar of the Mysore region of Karnataka state. The cultivar belongs to Musa spp., AAB, Silk subgroup, which is under threat of extinction, due its susceptibility to Fusarium wilt Race 1. In order to improve its resistance characters and create variation through mutagenesis, an investigation was carried out at Centre, for Horticulture Biotechnology, Bagalkot. The experiment was conducted with two chemical mutagens (EMS- $0.30 \%, 0.60 \%, 0.90 \%$ and $1.20 \%$ and $\mathrm{NaN}_{3}-0.01 \%, 0.02 \%$ and $0.03 \%$ ), of various concentrations. The lowest plant survival (52.50) and regeneration (87.50\%) was observed, from EMS at $1.20 \%$. With same EMS concentration, the days taken by the explants for spouting was 5.70 days, whereas, untreated control at 4.20 days. The minimum concentration of $\mathrm{NaN}_{3}$ at $0.01 \%$, recorded the highest (4.70 g) fresh weight and higher doses, invariably have minimum weights. Due to the stimulatory effects, lower concentrations of chemical mutagens, 100 per cent rooting was observed meanwhile, there was no rooting in EMS $1.20 \%$ treated microshoots. The mutagen concentrations of EMS at $0.90 \%$ and $\mathrm{NaN}_{3}$, at $0.01 \%$ have been found to be advantageous in creating variations.
\end{abstract}

KEYWORDS: Musa, Regeneration \& Microshoots

Received: Aug 03, 2017; Accepted: Aug 20, 2017; Published: Sep 11, 2017; Paper Id.: IJASROCT201723

\section{INTRODUCTION}

Bananas and plantains (Musa spp.) are widely grown in India, with great socioeconomic significance and interwoven in the cultural heritage of the country. Banana culture in India is as old as Indian civilization, and is one of the earliest fruit crops grown by mankind, at the dawn of civilization. The wide range of adoption of banana is due to its appreciable genetic diversity and suitability, to varied agro climatic conditions. The diverse agro climatic conditions have encouraged the development and sustenance of a large number of varieties, catering to local needs (Rajamanickamet al., 2006). The cultivar Nanjanagudu Rasabale (Musa spp., AAB, Silk subgroup), geographical indication tagged and once leading cultivar of the then Mysore province, is under threat of extinction due to its susceptibility to Panama disease (Poojaet al., 2013). The variant now, which is at the danger of extinction, has to strictly bred, by potential methodology to save and preserve as a germplasm.

Conventional breeding methods have been of limited success in Musa species, due to parthenocarpy, polyploidy in many cultivars, and limited available information on genetics and genomics (Chopra, 2005; Capdevilleet al., 2009). Mutation breeding and biotechnological methods can offer alternative tools, for banana improvement. Mutation breeding in vitro, is a powerful tool for the induction and selection of desirable mutants, 
which can be utilized in banana improvement, either for higher yields, good quality and resistance to biotic and abiotic factors (Purseglove, 1998). The purpose of mutation induction is to enhance the mutation rate, in a short duration, in developing new plant varieties. The occurrence of spontaneous mutation frequency rate is very low and difficult to use, in plant breeding.

Traditionally, mutations are induced by physical (e.g. Gamma radiation) and chemical (e.g. Ethyl Methane Sulphonate) mutagen treatment, of both seed and vegetative propagated crops (Jain, 2010). Chemical mutagens, generally produce induced mutation, which leads to base pair substitutions, especially $\mathrm{GC}^{\equiv} \mathrm{AT}$ resulting in an amino acid change, which change the function of proteins, but do not abolish their functions as deletions or frame shift mutations mostly do (El-Sayedet al., 2012). The mutants, so produced facilitate the isolation, identification and cloning of genes used in designing crops with improved yield and quality traits (Ahloowalia and Maluszynski, 2001). Keeping in view these considerations, an investigation was undertaken to study and analyze the efficacy of chemical mutagens, on crop improvement of Nanjanagudu Rasabale.

\section{MATERIALS AND METHODS}

The experiment was carried out, using the in vitro shoot tips of banana cv. Nanjanagudu Rasabale. To induce mutation, several chemicals have been used in banana. However, Ethyl Methane Sulphate (EMS) and Sodium Azide $\left(\mathrm{NaN}_{3}\right)$ has proved to be, one of the most effective chemicals.

\section{Methodology of Mutagen Treatment}

Mutagenic studies were carried out using the in vitro shoot tips, of Nanjanagudu Rasabale. The shoot tips were soaked in EMS (Ethyl Methane Sulphonate) and $\mathrm{NaN}_{3}$ (Sodium Azide), at different concentrations of 0.30, 0.60, 0.90, 1.20 per cent and 0.01, 0.02, 0.03 percent, respectively, along with control immersed in sterile water, for 30 minutes. These treated shoot tips were dried on blotting paper, to remove surface moisture. Later, the shoot tips were transferred to MS medium.

\section{Subculture, Rooting and Hardening}

After Ethyl Methane Sulphonate and Sodium Azide treatment's multiple shoot bud explants, were immediately transferred onto $\mathrm{M}_{1} \mathrm{~V}_{1}$ multiplication MS medium supplemented, with $4 \mathrm{mg} / \mathrm{l}$ benzyl amino purine (BAP), $30 \mathrm{~g} / \mathrm{l}$ sucrose and solidified with $7.0 \mathrm{~g} / \mathrm{l}$ of agar. Further, sub culturing was performed at an interval of 30 days, up to $\mathrm{M}_{1} \mathrm{~V}_{4}$ in order to dissociate chimeras. Individual shoots of $\mathrm{M}_{1} \mathrm{~V}_{4}$ cultures were cut and transferred on to $1 / 4^{\text {th }}$ strength of MS medium, supplemented with $2.0 \mathrm{mg} / \mathrm{l} \mathrm{IBA}$ and $3 \mathrm{~g} / \mathrm{l}$ activated charcoal, for induction of adventitious roots and to obtain rooted plantlets.

After rooting, plantlets were taken out of culture bottles and washed thoroughly, to remove agar medium adhered to the roots. The plantlets were treated with $1 \%$ Bavistin, for 5 minutes. Later, plantlets were transferred to a pro - tray containing sterilized coco peat, and kept under greenhouse for 4 weeks. Plants were further transferred to polybag containing red soil + sand + FYM (1:1:1 v/v), potting mixture and raised under shade house for six weeks.

\section{Statistical Analysis}

Analysis of variance, for effect of chemical mutagens on banana cv. Nanjanagudu Rasabale, in inducing variation was analyzed in a Completely Randomized Design (CRD). The levels of significance, used for the F - test was at 1 percent 
probability. Critical difference values were given in the table was at 1 percent level of significance, where the F-test was significant and used to compute the means. Values in the percentages were subjected to arcsine transformations, to ensure homogeneity. Wherever, values were 0 percent or 100 percent, $\operatorname{Arcsin}(1 / 4 n)$ and $\operatorname{Arcsin}(100-1 / 4 n)$, where $n$ is the number of observations, that make up the percentage, where the substituted, respectively.

\section{RESULTS AND DISCUSSIONS}

\section{Growth of Microshoots}

The data related to percent survival of explant was found to be statistically significant (Table 1). The minimum percent survival of explant (52.50) was observed in EMS 1.2\%, which was followed by $\mathrm{T}_{3}$ (91.25) EMS treatment. The maximum (100) percent survival of explant was observed in $\mathrm{T}_{1}, \mathrm{~T}_{2}, \mathrm{~T}_{5}$ and $\mathrm{T}_{8}$. It was found that, percent survival was reduced as the dosage of Ethyl Methane Sulphonate, increased from $0.30 \%$ to $1.20 \%$ and same trend was also observed in Sodium Azide treatments $(0.01 \%-0.03 \%)$. However, the percent survival was increased in a lower dose of mutagens, as the sub cultures increases after mutagenic treatments, except in Ethyl Methane Sulphonate concentration of $1.20 \%$, which showed a reduced response in subculture after subculture. The similar results were also found from reports of El-Sayedet al., 2012, who found incorporation of Sodium Azide into culture medium, affected the rate of plant survival, which was found to be decreasing with the concentration of Sodium Azide, increased from $1-3 \mathrm{mg} \mathrm{L}^{-1}$. The trends in response were also comparable with the studies of Bhagwat and Duncan (1998), which is generally accepted that, the frequency of mutations increases with an increase in dosage and dose rate.

Table 1: Effect of Different Doses of Ethyl Methane Sulphonate and Sodium Azide on Microshoots Growth in Banana Cv. Nanjanagudu Rasabale

\begin{tabular}{|l|c|c|c|c|c|}
\hline \multicolumn{1}{|c|}{ Treatments } & Per Cent Survival & $\begin{array}{c}\text { Per cent } \\
\text { Regeneration }\end{array}$ & $\begin{array}{c}\text { Days Taken } \\
\text { from Bud } \\
\text { Sprout }\end{array}$ & $\begin{array}{c}\text { Number of } \\
\text { Sprouts per } \\
\text { Explant }\end{array}$ & $\begin{array}{c}\text { Fresh Weight } \\
\text { (gm) }\end{array}$ \\
\hline $\mathrm{T}_{1}$-EMS at $0.30 \%$ & $100.00(89.71)^{*}$ & $100.00(89.71)^{*}$ & 4.53 & 3.24 & 4.20 \\
\hline $\mathrm{T}_{2}$-EMS at $0.60 \%$ & $100.00(89.71)^{*}$ & $100.00(89.71)^{*}$ & 5.20 & 2.91 & 3.60 \\
\hline $\mathrm{T}_{3}$-EMS at $0.90 \%$ & $91.25(75.44)^{*}$ & $100.00(89.71)^{*}$ & 5.40 & 2.83 & 3.40 \\
\hline $\mathrm{T}_{4}$-EMS at $1.20 \%$ & $52.50(46.44)^{*}$ & $87.50(72.30)^{*}$ & 5.70 & 2.30 & 2.30 \\
\hline $\mathrm{T}_{5}-\mathrm{NaN}_{3}$ at $0.01 \%$ & $100.00(89.71)^{*}$ & $100.00(89.71)^{*}$ & 4.30 & 3.45 & 4.70 \\
\hline $\mathrm{T}_{6}-\mathrm{NaN}_{3}$ at $0.02 \%$ & $100.00(89.71)^{*}$ & $100.00(89.71)^{*}$ & 4.45 & 3.86 & 3.83 \\
\hline $\mathrm{T}_{7}-\mathrm{NaN} \mathrm{N}_{3}$ at $0.03 \%$ & $97.50(85.17)^{*}$ & $95.00(83.17)^{*}$ & 4.68 & 3.28 & 3.67 \\
\hline $\mathrm{T}_{8}$-Untreated control & $100.00(89.71)^{*}$ & $100.00(89.71)^{*}$ & 4.20 & 4.24 & 3.45 \\
\hline S. Em. $\mathbf{\pm}$ & 2.43 & 2.39 & 0.07 & 0.17 & 0.10 \\
\hline CD @ 1\% & 9.63 & 9.47 & 0.28 & 0.66 & 0.40 \\
\hline
\end{tabular}

* Figures in parentheses indicate arcsine transformed values

The analyzed data indicated that, there was a reduction in the percent regeneration of explants, with an increase in the concentrations of mutagens. The maximum (100) percent regeneration was observed in all other mutagenic treatments and control. The minimum percent regeneration of explants (87.50) was observed in EMS $1.20 \%$, followed by $\mathrm{T}_{7}$ (95.00). These results are conformity with the results of Talebiet al., 2012, obtained indicate that, a reduction in seed germination occurred with a corresponding increase in EMS concentration. This also might be because; the proliferating buds are actively dividing explants with very few leaf sheaths, which would have made it more sensitive to mutagens. This is in conformity with the findings of Kantogluet al. 2010, who have also reported the differential sensitivity of explants, for mutagens. Similar results were also obtained from Bhagwat and Duncan (1998), for Ethyl Methane Sulphonate mutagenesis, the recommended treatment is $30 \mathrm{~min} / 200 \mathrm{mM}$. With this treatment, the highest FE (5.8) was obtained with a 
survival of $80 \%$ and shoot regeneration from $31.6 \%$ of apices. The regeneration obtained with this treatment was not significantly different from the $30 \mathrm{~min} / 100 \mathrm{mM}$ treatment, which resulted in 100\% survival and a lower FE (4.5).

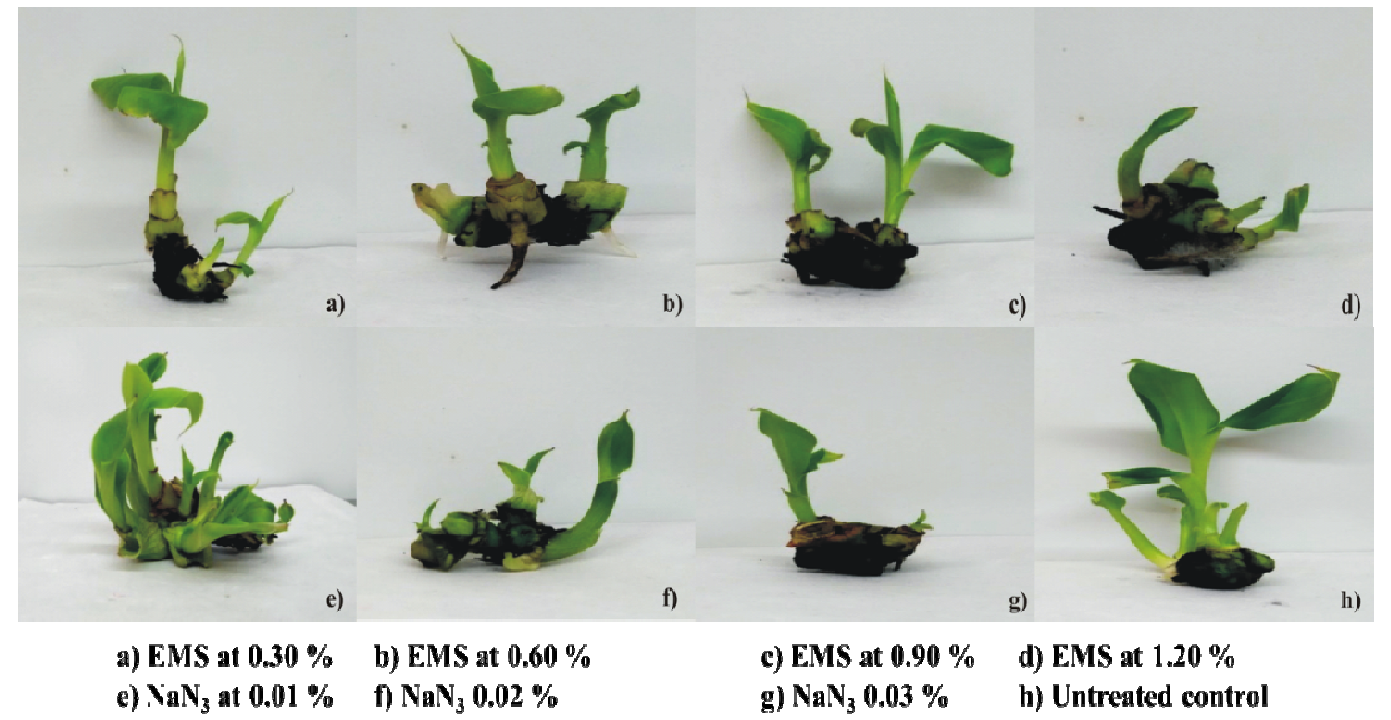

Figure 1: In Vitro Growth of Shoots Treated with Ethyl Methane Sulphate and Sodium Azide AT 120 Days after Mutagen Treatment

The lowest number of days for bud sprouting (4.20), was taken by Untreated control, which was on par with $\mathrm{T}_{5}$ and $\mathrm{T}_{6} 4.30$ and 4.45, respectively. The maximum days for (5.70) sprouting was observed in EMS $1.20 \%$, followed by $\mathrm{T}_{3}$ (5.40) and $\mathrm{T}_{2}$ (5.20). The increase in chemical concentration has increased the days taken for bud sprouting. This might be, due to varied chemical accumulation on the surface of the meristems, which interfered in the normal physiology of external growth. The similar statement was recorded by Saraswathiet al., 2016, the enhanced reactivity of the mutagen with the target tissues at higher concentrations and prolonged duration of the treatment. Prolonged treatments, with higher doses of mutagen are likely to result in a relatively higher physiological damage, in relation to the mutation rate.

EMS and $\mathrm{NaN}_{3}$, greatly affected sprouting of the explants. Among the treatments, maximum number of sprouts per explant (4.24) were observed in Untreated control, which was on par with $\mathrm{T}_{6}$ (3.86). The minimum (2.30) number of shoots per explant was observed in EMS $1.20 \%$, which was on par with $\mathrm{T}_{3}(2.83)$. The reduction in the number of shoots per explants, at higher concentrations of Ethyl Methane Sulphonate, may be due to chemo sensitivity of the cultivar. These results are comparable with the study of Omer et al., (1989) in banana cv. SH-3362. He reported that, chemo sensitivity was cultivar dependent and this could be attributed to genomic composition and ploidy levels, affecting accumulation of mutagenic compounds in the shoot tips, which is an essential step towards mutation induction.

The maximum shoot length (4.8) was observed in $\mathrm{NaN}_{3} 0.01 \%$, which was on par with $\mathrm{T}_{1}$ and $\mathrm{T}_{6}$ (4.70 and 4.33 respectively). The minimum (2.10) length of the shoot was observed in EMS 1.2\%, which was followed by $\mathrm{T}_{3}$ (3.05) at fourth sub culture. Growth was better at lower doses of chemical mutagens, as compared to higher doses. Similar results were also recorded by Tale biet al., 2012 who reported seedling height decreased in proportion with the increase in applied EMS concentration. This trend is quite common in the mutagen Zed population, such an effect is known to arise due to drastic chromosomal aberration, in addition to genetic mutations (El-Sayedet al., 2012).

From various chemical mutagen concentration, maximum fresh weight of explant (4.70) was obtained in $\mathrm{NaN}_{3}$ $0.01 \%$, which was followed by $\mathrm{T}_{1}$ and $\mathrm{T}_{6}$ (4.20 and 3.83 respectively). The minimum (2.30) fresh weight of explant was 
observed in EMS $1.20 \%$, which was followed by $\mathrm{T}_{3}$ (3.40) at fourth sub culture. The interaction for the average fresh weight of explant was found statistically significant. The reduction in weight at higher concentration, may be attributed to a reduction in the growth of the plantlets at higher concentrations, in banana cv. Kayinja was observed by Cieslaket al. (2012) and Musokeet al. (1999). Saraswathiet al., (2016) reported that, the fresh weight gain in untreated control was significantly higher than the mutagen treated explants. They also reported that, after three weeks of initiation, the fresh weight gain, decreased significantly with an increase in both the concentration of chemical mutagens and the duration of treatment.

\section{In Vitro Root Parameters}

In vitro rooting was induced in shoots of banana cv. Nanjanagudu Rasa bale, after four sub cultures (Table 2).

The effect of different doses of Ethyl Methane Sulphonate and Sodium Azide, on rooting of in vitro shoot tips was found to be significant. The maximum (100) percent rooting was observed in all treatments, except $\mathrm{T}_{3}$ and $\mathrm{T}_{6}(98.75$ and 95.00 respectively). This clearly shows that, the high dose of Ethyl Methane Sulphonate and Sodium Azide inhibited the rooting of in vitro shoot tips, that are attributed because of the chemo sensitivity of the mutagens. Our findings are comparable with Wi et al., 2007, who stated that, the high-dose treatment which caused growth inhibition has been ascribed to the cell cycle arrest, at G2/M phase during somatic cell division and/or various damages, in the entire genome.

Table 2: Effect of Different Doses of Ethyl Methane Sulphonate and Sodium Azide on Rooting of Microshootsin Banana Cv. Nanjanagudu Rasabale

\begin{tabular}{|l|c|c|c|c|c|}
\hline \multicolumn{1}{|c|}{ Treatments } & $\begin{array}{c}\text { Per Cent } \\
\text { Rooting }\end{array}$ & $\begin{array}{c}\text { Length of } \\
\text { Primary } \\
\text { Root }(\mathbf{c m})\end{array}$ & $\begin{array}{c}\text { Length of } \\
\text { Longest } \\
\text { Root }(\mathbf{c m})\end{array}$ & $\begin{array}{c}\text { Number of } \\
\text { Secondary } \\
\text { Root }\end{array}$ & $\begin{array}{c}\text { Number of } \\
\text { Primary } \\
\text { Root }\end{array}$ \\
\hline $\mathrm{T}_{1}$-EMS at $0.30 \%$ & $100.00(89.71)^{*}$ & $6.30(2.59)^{+}$ & $8.30(2.99)^{+}$ & $53.00(7.30)^{+}$ & $3.40(1.96)^{+}$ \\
\hline $\mathrm{T}_{2}$-EMS at $0.60 \%$ & $100.00(89.71)$ & $5.70(2.49)$ & $14.40(3.84)$ & $67.00(8.20)$ & $3.60(2.02)$ \\
\hline $\mathrm{T}_{3}$-EMS at $0.90 \%$ & $95.00(83.14)$ & $4.60(2.23)$ & $9.80(3.20)$ & $32.00(5.67)$ & $5.60(2.44)$ \\
\hline $\mathrm{T}_{4}$-EMS at $1.20 \%$ & $0.00(0.28)$ & $0.00(0.70)$ & $0.00(0.70)$ & $0.00(0.70)$ & $0.00(0.70)$ \\
\hline $\mathrm{T}_{5}$-NaN ${ }_{3}$ at $0.01 \%$ & $100.00(89.71)$ & $5.10(2.34)$ & $10.30(3.31)$ & $69.00(8.33)$ & $2.90(1.80)$ \\
\hline $\mathrm{T}_{6}-\mathrm{NaN}_{3}$ at $0.02 \%$ & $98.75(86.55)$ & $4.30(2.17)$ & $9.60(3.20)$ & $47.00(6.88)$ & $3.10(1.91)$ \\
\hline $\mathrm{T}_{7}-\mathrm{NaN}_{3}$ at $0.03 \%$ & $100.00(89.71)$ & $3.80(2.05)$ & $6.80(2.73)$ & $28.00(5.32)$ & $3.70(2.02)$ \\
\hline $\mathrm{T}_{8}$-Untreated control. & $100.00(89.71)$ & $5.40(2.44)$ & $9.40(3.151)$ & $36.00(6.03)$ & $4.20(2.16)$ \\
\hline S. Em. $\mathbf{\pm}$ & 1.82 & 0.28 & 0.33 & 2.61 & 0.47 \\
\hline CD @ 1\% & 7.21 & 1.09 & 1.32 & 10.31 & 1.87 \\
\hline
\end{tabular}

* Figures in parentheses indicate arcsine transformed values

The longest root was observed in EMS $0.60 \%$, followed by $\mathrm{T}_{5}$ and $\mathrm{T}_{3}$ (10.30 and 9.80, respectively). The minimum (6.30) length of longest root was observed in $\mathrm{NaN}_{3} 0.03 \%$, which was on par with $\mathrm{T}_{1}(8.30)$ and $\mathrm{T}_{8}(9.40)$. Significantly, highest (6.30) length of primary root was observed in $\mathrm{T}_{1} \mathrm{EMS} 0.30 \%$, which was on par with $\mathrm{T}_{5}$ and $\mathrm{T}_{8}(5.70$ and 5.40 respectively). The minimum (3.80) length of primary root was observed in $\mathrm{NaN}_{3} 0.03 \%$, which was on par with $\mathrm{T}_{6}$ (4.30) and $\mathrm{T}_{3}$ (4.60). The inhibitory effect of Ethyl Methane Sulphonate and Sodium Azide, was observed in the case of length of the longest and primary root production. The highest length of roots was obtained from Ethyl Methane Sulphonate $(0.60 \%$ and $0.90 \%)$ and Sodium Azide (0.01\%), treated shoot tips as compared with control. Again, reduction in root length occurred with a corresponding increase in the concentration of Ethyl Methane Sulphonate. This might be attributed to the interference in the synthesis of IAA, at higher doses of mutagen. These findings are comparable with Karmakaret al., 2000, statements that high dose of mutagens, generally induce harmful effects on rooting. Such harmful effects have often been considered, due to interference in the normal physiological functioning. 
The maximum (5.60) number of primary roots was recorded in EMS $0.90 \%$, which was on par with $\mathrm{T}_{8}$ (4.20). The minimum number (2.90) of primary roots was observed in $\mathrm{NaN}_{3} 0.01 \%$. Among, the treatments, maximum (69.00) number of secondary roots were recorded in $\mathrm{NaN}_{3} 0.01 \%$, which was on par with $\mathrm{T}_{2}(67.00)$. The minimum number (28.00) of secondary roots was observed in $\mathrm{T}_{7} \mathrm{NaN}_{3} 0.03 \%$, which was on par with $\mathrm{T}_{3}(32.00)$ and $\mathrm{T}_{8}(36.00)$. In the present study, the results of analyzing data related to the number of primary and secondary roots per plantlet, revealed significant differences for chemical mutagens. The highest number of smaller primary roots was obtained from Ethyl Methane Sulphonate $0.90 \%$, as compared with control. The maximum secondary roots were produced from Sodium Azide $0.01 \%$, which is because of the stimulatory effect of Sodium Azideat lower concentration that increased the number of roots (Salimet al., 2009).

\section{REFERENCES}

1. Ahloowalia, B. S, and Maluszynski, M., 2001, Induced mutations: A new paradigm in plant breeding. Euphytica., 118: 167173.

2. Bhagwat, B. And Duncan, E. J., 1998, Mutation breeding in banana cv. Highgate (Musa spp., AAA Group) for tolerance to Fusarium oxysporumf. sp. cubense using chemical mutagens. Sci. Hortic., 73: 11-22.

3. Capdeville, G., Souza, M.T., Szinay, D., Wijnker, E. And De-Jong, H., 2009, The potential of high-resolution BAC-FISH in banana breeding. Euphytica., 166: 431-443.

4. Ceislak, J.J., Huynh, O. A., Brozynska, M., Nakitandwe, J. And Bradley, T.J., 2012, Induction, rapid fixation and retention of mutations in vegetatively propagated banana. Plant Biotechnol. J., 10: 1056-1066.

5. Chopra, V.L., 2005, Mutagenesis: investigating the process and processing the outcome for crop improvement. Curr. Sci., 89: 353-359.

6. El-Sayed, H.E., Sherin A.M., Shaltout, A.D., El-Dougdoug and Sayed, R.A., 2012, Chemical mutation induction in vitro cultured shoot tip of banana cv. Grand Nain for resistance some virus diseases. International J. Virol., 8 (2): 178-190.

7. Jain, S.M., 2010, Mutagenesis in crop improvement under the climate change. Romanian Biotechnological Letters, 15 (2): 88 106.

8. Kantoglu, Y., Secer, E., Erzurum, K., Tutluer, I., Kunter, I., Peskircioslu, H. And Sagel, Z., Improving tolerance to Fusarium oxysporumf. Sep. melonis in melon using tissue culture and mutation techniques: Mass screening techniques for selecting crops resistant to disease (International Atomic Agency, Vienna) 2010, 235.

9. Karmkar, V.M., Kulkarni, V.M., Suprasanna, P., Bapat, V.A. And Rao, P.S., 2001, Radio-sensitivity of in vivo and in vitro cultures of banana cv. Basrai (AAA). Fruits, 56 (2): 67-74.

10. Musoke, C., Rubaihayo and Magambo, M., 1999, Gamma Rays and Ethylmethane Sulphonate In vitro Induced Fusarium Wilt Resistant Mutants in Bananas.Afr. Crop Sci. J., 7 (4): 313-320.

11. Omar. M.S., Novak, F.J. And Brunner, H., 1989, In vitro action of ethylmethanesulphonate on banana shoot-tips. Sci. Hort., 40: $283-297$.

12. Pooja, B., Ajit, A.W. And Umesha, K., 2013, Preliminary assessment of intra-clonal variations in Indian banana varieties for sucker production. IND. J. Natural products and resources., 4 (4): 387-391.

13. Purseglove, J. W., 1998, Tropical crops. Monocotyledons. Longman Scientific and Technical. Longman Group UK. Ltd. Pp. 607. 
14. Rajamanickam, C., Rajmohan, K., Parthiban, S. And Venkateshan, K., 2006, Performance of triploid banana (Musa spp.) cultivars of Kerala. South Indian Hort., 55 (1-6): 119-132.

15. Salim, K., Fahad Al-Qurainy, and Firoz, A., 2009, Sodium Azide: a Chemical Mutagen for Enhancement of Agronomic Traits of Crop Plants. Environ. We Int. J. Sci. Tech., 4:1-21.

16. Saraswathi, M.S., Kannan, G., Uma, S., Thangavelu, R. And Backiyarani, S., 2016, Improvement of banana cv. Rasthali (Silk, $A A B)$ against Fusarium oxysporumf.sp.cubense (VCG 0124/5) through induced mutagenesis: Determination of LD $D_{50}$ specific to mutagen, explants, toxins and in vitro and in vivo screening for Fusarium wilt resistance. Indian J. Exp. Biol., 54: 345-353.

17. Talebi, A.B., Talebi2, A.B. And Shahrokhifar, B., 2012, Ethyl Methane Sulphonate (EMS) Induced Mutagenesis in Malaysian Rice (cv. MR219) for Lethal Dose Determination. A. J. P. S., 3: 1661-1665.

18. Wi, S.G., Chung, B.Y., Kim, J.S., Kim, J.H., Baek, M.H., Lee, J.W. And Kim, Y.S., 2007, Effects of Gamma Irradiation on Morphological Changes and Biological Responses in Plants. Micron, Vol. 38, No. 6, pp. 553-564. 
